\title{
Highbush Blueberry Cultivars Differ in the Relationship between Seed Number and Berry Weight during the Harvest Season
}

\author{
Bernadine C. Strik and Amanda J. Vance \\ Department of Horticulture, Oregon State University, 4017 ALS, Corvallis, \\ OR 97331
}

Additional index words. fruit set, berry size, pollination, seed set, Vaccinium corymbosum

\begin{abstract}
The relationship between individual berry weight and viable seed number of small- $(<15 \mathrm{~mm})$, medium- $(15-19 \mathrm{~mm})$, and large-diameter $(>19 \mathrm{~mm})$ berries was studied over 2 years in nine cultivars (Aurora, Bluecrop, Bluegold, Draper, Duke, Liberty, Legacy, Ozarkblue, and Reka) through their harvest seasons. Plants were grown with two different preplant amendment-mulch treatments, but this treatment had no effect on the variables measured, so data were pooled. The highest average seeds/berry was in 'Bluecrop' (55.5) and 'Duke' (50.0) and the lowest in 'Bluegold' (17.1), 'Aurora' (22.5), and 'Liberty' (23.5). Average berry weight over the fruiting season ranged from 1.79 and $1.80 \mathrm{~g}$ for 'Liberty' and 'Reka', respectively, to 2.30 and $2.44 \mathrm{~g}$ in 'Ozarkblue' and 'Draper', respectively. The average number of seeds/berry was higher in 2010 than in 2009 for all cultivars, ranging from $14 \%$ higher in 'Reka' to $96 \%$ higher in 'Liberty'. The flowering period was earlier in 2010 than in 2009, but bloom was concentrated in 2009 ( 28 days) compared with 2010 (45 days), likely affecting pollinator success. In general, seeds/berry and berry weight declined through the harvest season. Some cultivars had a considerable difference in the number of seeds in large-sized than in small-sized berries (e.g., 89\%, 107\%, 108\%, and 147\% more seeds in 'Aurora', 'Reka', 'Bluegold', and 'Liberty', respectively), whereas others had relatively little difference (14\% and 36\% in 'Draper' and 'Bluecrop', respectively). There was a linear relationship between berry weight and viable seeds/berry. Cultivars did not differ in the berry weight per seed (slope of the line) between the 2 years, except for 'Draper' (only significant in 2009), 'Legacy', and 'Reka'. 'Bluegold' had the greatest berry weight per seed and 'Reka' the lowest. The weakest relationship between berry weight and seed number was in 'Draper'. Cultivars that produced parthenocarpic fruit of marketable size were 'Aurora', 'Bluegold', and 'Liberty'. 'Duke', 'Legacy', 'Reka', and 'Ozarkblue' produced commercially acceptable fruit $(0.75-1.0 \mathrm{~g})$ with fewer than 7 seeds/berry. By contrast, some cultivars required a relatively large number of seeds to produce a berry including 'Bluecrop' (28-40 seeds), 'Draper' (15-23 seeds), and 'Legacy' in 2010 (20 seeds). The number of seeds per berry accounted for as much as $87 \%$ of the variability in berry weight indicating the importance of good pollination and seed set for berry weight and yield in these cultivars.
\end{abstract}

In blueberry (Vaccinium spp.), issues related to poor pollination are considered as important production problems in many regions (e.g., Oregon Blueberry Commission, 2018; Northwest Center for Small Fruits Research, 2018; Washington Blueberry Commission, 2018). In particular, growers are concerned with poor fruit set (the proportion of flowers that become

Received for publication 2 May 2019. Accepted for publication 21 June 2019

The authors value the assistance of Gil Buller and Emily Vollmer, former Faculty Research Assistants at the North Willamette Research and Extension Center, Sabry Elias, Dept. Crop and Soil Sci. OSU, Seed Laboratory for training and loan of seed counting equipment, and Cliff Pereira, for assistance on statistical analysis. We appreciate the funding support provided by the Oregon Blueberry Commission.

B.C.S. is the corresponding author. E-mail: bernadine. strik@oregonstate.edu.
Isaacs, 2012; Moore, 1964), coupled with impacts of weather on pollen deposition, pollen germination, pollen tube growth, and ovule fertilization (Stephenson et al., 1992) may further limit fruit and seed set. The main pollinator used in commercial blueberry fields is the honey bee (Apis mellifera L.). Reduced air temperature $\left(<12{ }^{\circ} \mathrm{C}\right)$, wind speeds above 20 $\mathrm{kph}$, and precipitation reduced honey bee activity and correspondingly the number of seeds/ berry (Tuell and Isaacs, 2010). Honey bee visitation rates were correlated with the number of seeds per berry (seeds/berry) and correspondingly with berry weight (DeVetter et al., 2016). Nutrient deficiencies within the flower may limit seed set (Chen et al., 1998; May and Killingbeck, 1992).

Cultivars differ in percent fruit set or seed set because of differing bloom periods and associated differences in weather (Arrington and DeVetter, 2017), differences in attractiveness of the flowers to pollinators (Courcelles et al., 2013), and genetic differences in self- or cross-compatibility and pollen quantity or quality (e.g., Brewer and Dobson, 1969; Chavez and Lyrene, 2009; Ehlenfeldt and Kramer, 2012; MacKenzie, 1997; Rabaey and Luby, 1988; Vander Kloet, 1983). As a result, cultivars have been found to differ in the seeds/berry and, often as a result, berry size (Arrington and DeVetter, 2018; Brewer and Dobson, 1969; DeVetter et al., 2016; Eaton, 1967; Ehlenfeldt, 2001; Ehlenfeldt and Martin, 2010; Gupton, 1984; Gupton and Spiers, 1994; Jackson et al., 1972; Lang and Danka, 1991; Lyrene, 1989; Meader, 1936; Meader and Darrow, 1944, 1947; Moore et al., 1972; Morrow, 1943; Payne et al., 1989; Taber and Olmstead, 2016).

Cultivars differ in the berry weight per seed (Bailey, 1938; Brewer and Dobson, 1969; Eaton, 1967; Gupton, 1984; Knight and Scott, 1964; Lyrene and Goldy, 1983; Meader and Darrow, 1944; Rabaey and Luby, 1988; Taber and Olmstead, 2016). It is possible that cultivars vary in growth hormones produced by the fertilized ovules or developing seeds (Mainland and Eck, 1968; Meader and Darrow, 1944, 1947; Moore et al., 1972). With poor seed set, parthenocarpic fruit may be induced by exogenous application of gibberellic acid, but these berries remain small compared with pollinated fruit with seeds (Barker and Collins, 1965; Williamson et al., 1995).

There are many highbush blueberry cultivars grown in the northwestern United States (Strik et al., 2014), some of which are reported to have more variability in berry weight and fruit set than others (e.g., 'Liberty' and 'Draper'). Our objectives were to determine 1) whether the commonly grown cultivars differ in the number of seeds/berry, and 2) the relationship between seeds/berry on berry diameter, harvest season, and berry weight. This information will enhance our understanding of the importance of good pollination and potentially explain differences observed among cultivars. 


\section{Materials and Methods}

The study was conducted in 2009 to 2010 in a planting of highbush blueberry established in Oct. 2006 at Oregon State University's North Willamette Research and Extension Center (NWREC, Aurora, OR; lat. $45^{\circ} 16^{\prime} 47^{\prime \prime} \mathrm{N}$, long. $122^{\circ} 45^{\prime} 23^{\prime \prime} \mathrm{W}$ ). Weather data for this site are available from an AgriMet weather station (U.S. Dept. Interior, 2014). Soil at the site was a Willamette silt loam (fine-silty mixed superactive mesic Pachic Ultic Argixeroll) and had a $\mathrm{pH}$ of $4.9 \%$ and $3.7 \%$ organic matter at planting. Plants were irrigated using a single line of polyethylene drip tubing (Netafim, Fresno, $\mathrm{CA})$ with $2 \mathrm{~L} \cdot \mathrm{h}^{-1}$ pressure-compensating, inline emitters spaced every $0.3 \mathrm{~m}$. Plant spacing was $0.8 \mathrm{~m}$ by $3.0 \mathrm{~m}$ (4385 plants/ ha). A permanent grass cover crop was grown in the row aisles and mowed during the growing season, as required. Additional details of planting establishment, management, fertilization, and leaf nutrient sufficiency levels are published elsewhere (Strik et al., 2017; Strik and Vance, 2015). Honey bees were introduced to the field at $\approx 5 \%$ to $10 \%$ bloom at a stocking rate of 10 hives/ha.

Nine cultivars (Aurora, Bluecrop, Bluegold, Draper, Duke, Liberty, Legacy, Ozarkblue, and Reka) were planted with two different preplant amendment-mulch treatments. The "compost + sawdust" treatment included a preplant amendment and a mulch of municipal yard debris compost and sawdust, while the "weed mat" treatment involved no preplant amendment but included a mulch of fresh douglas fir [Pseudotsuga menziesii (Mirb.) Franco var. menziesii] sawdust topped with black, woven polyethylene groundcover. Additional information on amendment-mulch treatments are reported in Strik et al. (2017). There were two replicates of each cultivar-amendmentmulch treatment combination, and plots consisted of seven plants each. The design of the planting with nine cultivars and a good stocking rate of honey bees-ensured pollination (self- or cross-) was not limiting if weather was favorable. Data were collected on the date of $5 \%$ bloom and full bloom for each cultivar.

Whole plots of each cultivar were harvested by hand at a commercial stage of ripeness at $\approx 7$ - to 10 -d intervals, between two and five times per year, depending on the cultivar and the associated length of the fruiting season. On each of harvest $1-5$, a subsample of fruit from each plot was divided into three berry size categories, small ( $<15 \mathrm{~mm})$, medium $(15-19 \mathrm{~mm})$, and large $(>19 \mathrm{~mm})$ diameter, and 10 berries from each size category were individually weighed and frozen for later analysis of seed number.

Seeds were separated from skin and pulp and prepared for counting using the procedure published by Ehlenfeldt and Martin (2010). A $32 \times 32$ wire mesh screen (0.57mm-diameter holes) was used to separate seeds considered viable (presumed to contain a live embryo) from smaller, unviable seeds that passed through the sieve. Seed viability was determined using a tetrazolium chloride assay (Patil and Dadlani, 2009) of all seeds from a subsample of 10 large-diameter 'Bluecrop' fruit. Seeds were separated into seven size categories, and live embryos were only found in seeds larger than $0.57 \mathrm{~mm}(100 \%)$; these seeds were plump and darker in color. Seeds smaller than $0.57 \mathrm{~mm}$ were flat and lighter colored and were determined to be unviable; these were not included in the seed counts and data reported herein. Our perception of the visible differences between viable and nonviable seeds agreed with others (Dogterom et al., 2000; Ehlenfeldt and Martin, 2010; Morrow, 1943), but we found that viable seeds were smaller than previously reported (Dogterom et al., 2000).

For each berry, the seeds remaining after sieving were weighed before counting using an electronic seed counter (Model 850-2; The Old Mill Co., Savage, MD). The machine was calibrated to confirm accurate seed counts against a known number of seeds. Stone cells, which were separated from the pulp along with the viable seeds, were counted and subtracted from the number of seeds counted. The number of seeds/berry and berry weight were recorded for individual fruit within berry size categories for each harvest, as described previously. The seed number per gram of berry was calculated.

Statistical analyses were performed using SAS 9.3 (Cary, NC). An initial analysis using PROC MIXED was performed to determine the effects of year, amendment-mulch, and cultivar. Amendment-mulch had no significant effects on seed number or berry weight (data not shown) and did not interact with the significant effects of year and cultivar, so the data were pooled providing four replicates for the remaining analyses. A split-plot analysis was performed by cultivar to evaluate the year (main plot, $\mathrm{n}=2$ ), harvest number (subplot, $\mathrm{n}=2$ to 5 , depending on cultivar), and berry size category effects (nested subplot, $n=3$ ). PROC REG was used to de- termine the linear relationship between seeds/berry and berry weight by cultivar. The effect of year and cultivar on the minimum and maximum number of seeds/berry was analyzed using PROC MIXED. Means were separated at the 5\% level using Tukey's honest significant difference test.

\section{Results and Discussion}

Year and cultivar effects. There was an effect of cultivar and a year by cultivar interaction $(P<0.0001)$ on the average number of viable seeds/berry, berry weight, and seeds per gram of berry weight but no effect of amendment-mulch (data not shown). The highest average seeds/berry was found in 'Bluecrop' (55.5) and 'Duke' (50.0) and the lowest in 'Bluegold' (17.1), 'Aurora' (22.5), and 'Liberty' (23.5). Average berry weight ranged from as low as 1.79 and $1.80 \mathrm{~g}$ for 'Liberty' and 'Reka', respectively, to 2.30 and $2.44 \mathrm{~g}$ in 'Ozarkblue' and 'Draper', respectively. On average, 'Bluecrop', 'Duke', 'Legacy', and 'Reka' had the highest number of seeds per gram of berry weight (21.7-28.1) and 'Aurora', 'Bluegold', 'Liberty', and 'Ozarkblue' the fewest (8.0 13.7).

There was an effect of year on the average minimum and maximum number of viable seeds/berry, across all cultivars, harvest numbers, and berry size categories with lower levels in 2009 than in 2010 (Table 1). 'Bluecrop', 'Duke', and 'Reka' had the highest maximum number of seeds/berry, whereas 'Bluegold' and 'Aurora' had the lowest. 'Bluecrop' also had the highest minimum number of seeds/berry, whereas 'Aurora', 'Bluegold', 'Liberty', and 'Reka' had the lowest. Most cultivars had little difference between years for the maximum number of seeds/berry. However, 'Bluecrop' and 'Legacy' had a higher maximum seeds/berry in 2010 than in 2009 (data not shown).

The weight of seeds/berry was greater in 2010 than in 2009 and cultivars differed in

Table 1. The effect of northern highbush blueberry cultivar and year on the number of seeds, seed weight, and the number of stone cells per berry, averaged over harvest number and amendment mulch.

\begin{tabular}{lcccc}
\hline & \multicolumn{2}{c}{ Seeds/berry } & & \\
\cline { 2 - 3 } & Maximum & Minimum & Seed wt (mg/berry) & Stone cells/berry (no.) \\
\hline Year & & & & \\
2009 & $46 \mathrm{~b}^{\mathrm{y}}$ & $11 \mathrm{~b}$ & $9.5 \mathrm{~b}$ & 0.8 \\
2010 & $55 \mathrm{a}$ & $21 \mathrm{a}$ & $14.0 \mathrm{a}$ & 0.9 \\
Cultivar & & & $9.2 \mathrm{~g}$ \\
Aurora & $37 \mathrm{~d}$ & $6 \mathrm{~d}$ & $9.2 \mathrm{e}$ & $1.3 \mathrm{ab}$ \\
Bluecrop & $65 \mathrm{a}$ & $38 \mathrm{a}$ & $19.4 \mathrm{a}$ & $0.3 \mathrm{fg}$ \\
Bluegold & $26 \mathrm{e}$ & $7 \mathrm{~d}$ & $4.4 \mathrm{f}$ & $1.3 \mathrm{ab}$ \\
Draper & $45 \mathrm{c}$ & $26 \mathrm{~b}$ & $11.6 \mathrm{~cd}$ & $0.7 \mathrm{de}$ \\
Duke & $69 \mathrm{a}$ & $19 \mathrm{bc}$ & $13.2 \mathrm{c}$ & $1.4 \mathrm{a}$ \\
Legacy & $54 \mathrm{~b}$ & $20 \mathrm{bc}$ & $15.3 \mathrm{~b}$ & $0.9 \mathrm{~cd}$ \\
Liberty & $41 \mathrm{~cd}$ & $7 \mathrm{~d}$ & $9.7 \mathrm{de}$ & $0.5 \mathrm{ef}$ \\
Ozarkblue & $53 \mathrm{~b}$ & $13 \mathrm{~cd}$ & $12.0 \mathrm{c}$ & $1.1 \mathrm{bc}$ \\
Reka & $64 \mathrm{a}$ & $10 \mathrm{~d}$ & $11.8 \mathrm{c}$ & $\mathrm{NS}$ \\
Significance & & & $<0.0001$ \\
Year & $<0.0001$ & $<0.0001$ & $<0.0001$ & $<0.0001$ \\
Cultivar & $<0.0001$ & $<0.0001$ & $<0.0001$ & \\
Year $\times$ cultivar & $<0.0001$ & $\mathrm{NS}$ & & \\
\hline
\end{tabular}

${ }^{\mathrm{z}}$ Results from analysis of variance. Nonsignificant (NS) or actual $P$ value provided when significant $(P<$ $0.05)$.

${ }^{\mathrm{y}}$ Means followed by the same letter within treatment are not significantly different (LSMEANS) $(P>0.05)$. 


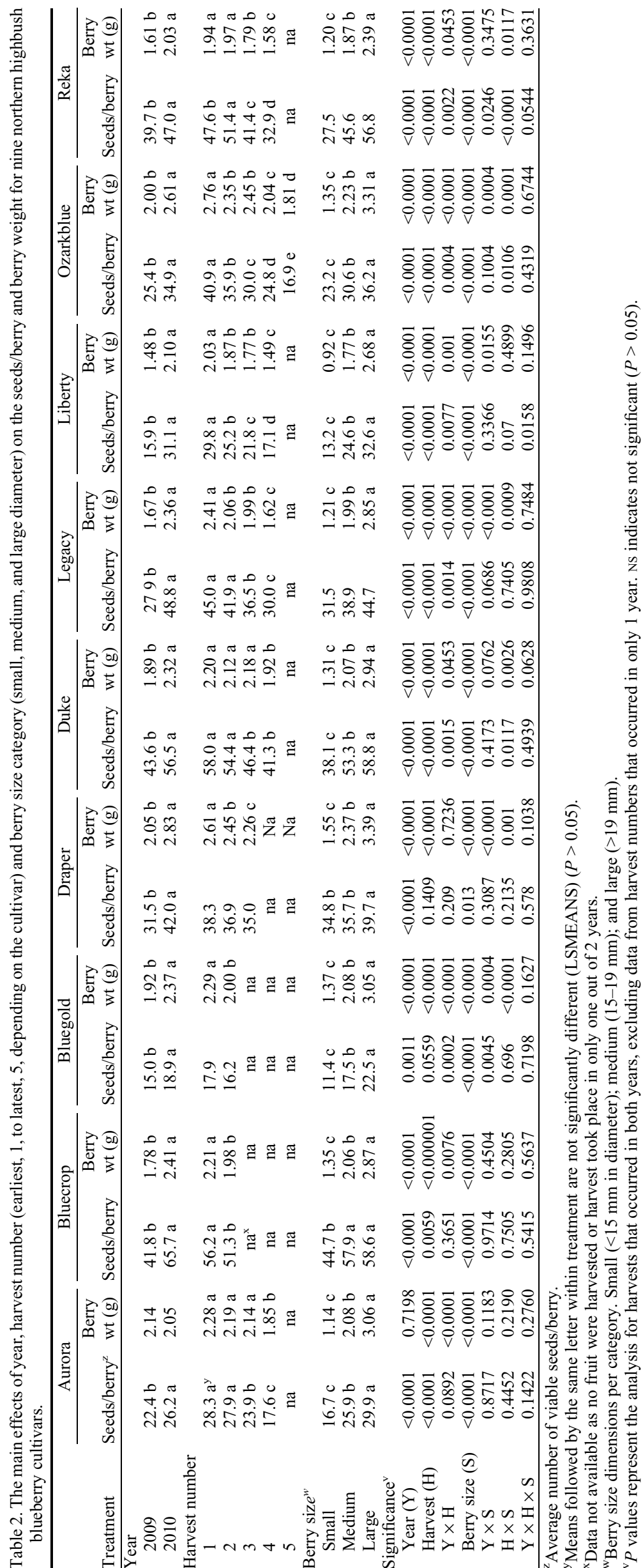

seed weight/berry with 'Bluecrop' having the most and 'Bluegold', 'Aurora', and 'Liberty' the least. Moore et al. (1972) found that seed size differed among highbush blueberry cultivars, but this was not related to berry weight. On average, there was less than one stone cell per berry, but cultivars differed with 'Legacy' having the highest and 'Aurora' and 'Bluegold' the fewest (Table 1).

Others have reported cultivar differences in seeds/berry in blueberry (e.g., Darrow, 1958; Ehlenfeldt and Kramer, 2012; Taber and Olmstead, 2016). The average numbers of seeds/berry reported here are higher than what has been reported for the same cultivars in other studies. For example, MacKenzie (1997) reported an average of 20 to 24 seeds/berry in open pollinated 'Bluecrop', depending on year, whereas Dogterom et al. (2000) found 48 seeds/berry in 'Bluecrop'. Ehlenfeldt and Martin (2010) reported 24-50 and 21-42 seeds/berry in 'Bluecrop' and 'Duke', respectively, with a minimum seed number of 8-30, depending on year. In our study, minimum seed number also varied greatly among cultivars. In Washington, Arrington and DeVetter (2018) found fewer seeds/berry in 'Duke' (1133) than in our study, but also reported lower fruit set in their region, likely because of adverse weather reducing pollinator activity (Arrington and DeVetter, 2017). Increased pollinator activity through stocking with more hives/ha increased seeds/berry (Arrington and DeVetter, 2018). Although Ehlenfeldt and Martin (2010) reported that an early-ripening cultivar had fewer seeds and smaller berries than a later ripening cultivar, we found no such relationship. The earliest fruiting cultivar in our study was 'Duke', which had the highest average seeds/berry and the largest berry weight. By contrast, the latest ripening cultivar Aurora had large berries with lower average seeds/berry.

Year, harvest number, and berry size category effects by cultivar. There was a significant effect $(P \leq 0.05)$ of year on the average seeds/berry in all cultivars and on berry weight in all except for 'Aurora' (Table 2). Weather, particularly rain and temperature, affects the activity of honey bees and can, thus, affect fruit set or seed set (DeVetter et al., 2016; Tuell and Isaacs, 2010). Although we did not measure percent fruit set, Strik et al. (2017) reported an average fruit set of $93 \%(2008-13)$ in this planting, and we observed good pollinator activity during the study. Multiple visits by bees to a flower are required for pollination in blueberry because deposition of higher numbers of pollen tetrads increase seed set or seeds/berry (Dogterom et al., 2000). They found that providing excess pollen to 'Bluecrop' flowers with an average of 106 ovules led to 48 large, plump seeds for a seed set of $45 \%$. Moore et al. (1972) reported a seed set ranging from $22 \%$ to $52 \%$, depending on cultivar, with $52 \%$ in 'Bluecrop'.

The average number of seeds/berry was higher in 2010 than in 2009 for all cultivars, ranging from $14 \%$ higher in 'Reka' to $96 \%$ 
higher in 'Liberty'. The flowering period started earlier $5 \%$ bloom from 24 Mar. to 20 Apr.) and full bloom was earlier (18 Apr.6 May) in 2010 than in 2009 (5\% bloom from 15 to 30 Apr.; full bloom 2-15 May) because of a warmer late-winter period in 2010 (data not shown). In addition, bloom was concentrated in 2009 (28 d) compared with 2010 (45 d). Although there were more rain events during the bloom season in 2010 than in 2009 (30 and $14 \mathrm{~d}$, respectively) and a higher volume of rain (190 and $104 \mathrm{~mm}$, respectively), it was considerably warmer in 2009 than in 2010 (Fig. 1). If temperatures get too warm (potentially above $20^{\circ} \mathrm{C}$ ), the effective pollination period or pollen fertility may be reduced (Kirk and Isaacs, 2012; Stephenson et al., 1992), potentially decreasing the seed set. The more concentrated bloom period in
2009 may also have limited pollinator effectiveness with more flowers open at once, yet the same number of hives per hectare coupled with a possibly shorter effective pollination period due to warmer temperatures. Although 'Legacy' and 'Reka' were the earliest to reach $5 \%$ bloom in both years, all nine cultivars overlapped considerably in the bloom period (data not shown).

Harvest number had a significant effect on seeds/berry in all cultivars, except for 'Bluegold' $(P=0.06)$ and 'Draper' ( $P=$ $0.14)$, and on berry weight in all cultivars, both declining through the harvest season (Table 2). There was a year by harvest number interaction on seeds/berry in six cultivars (Fig. 2). There were more harvests in 2010 than in 2009 in 'Bluegold', 'Legacy', and 'Reka', likely because of the prolonged bloom period (Fig. 1). In 'Bluegold', 'Legacy', 'Duke', and 'Liberty', the seeds/berry was more consistent among harvest dates in 2010 than in 2009, when seeds/berry declined more rapidly (Fig. 2). In 'Ozarkblue', the seeds/berry declined from the first through the fifth harvests in both years (Fig. 2E). Our results agree with others who reported a decrease in seeds/ berry with progressively later harvests (Brewer and Dobson, 1969; Darrow, 1958; Ehlenfeldt and Martin, 2010; Moore et al., 1972). The decrease in seeds/berry over the harvest season may be related to less adequate pollination in later opening flowers (Brewer and Dobson, 1969), fewer ovules in later opening flowers (Moore et al., 1972), or a decrease in the percent seed set as shown by Meader and Darrow (1947).

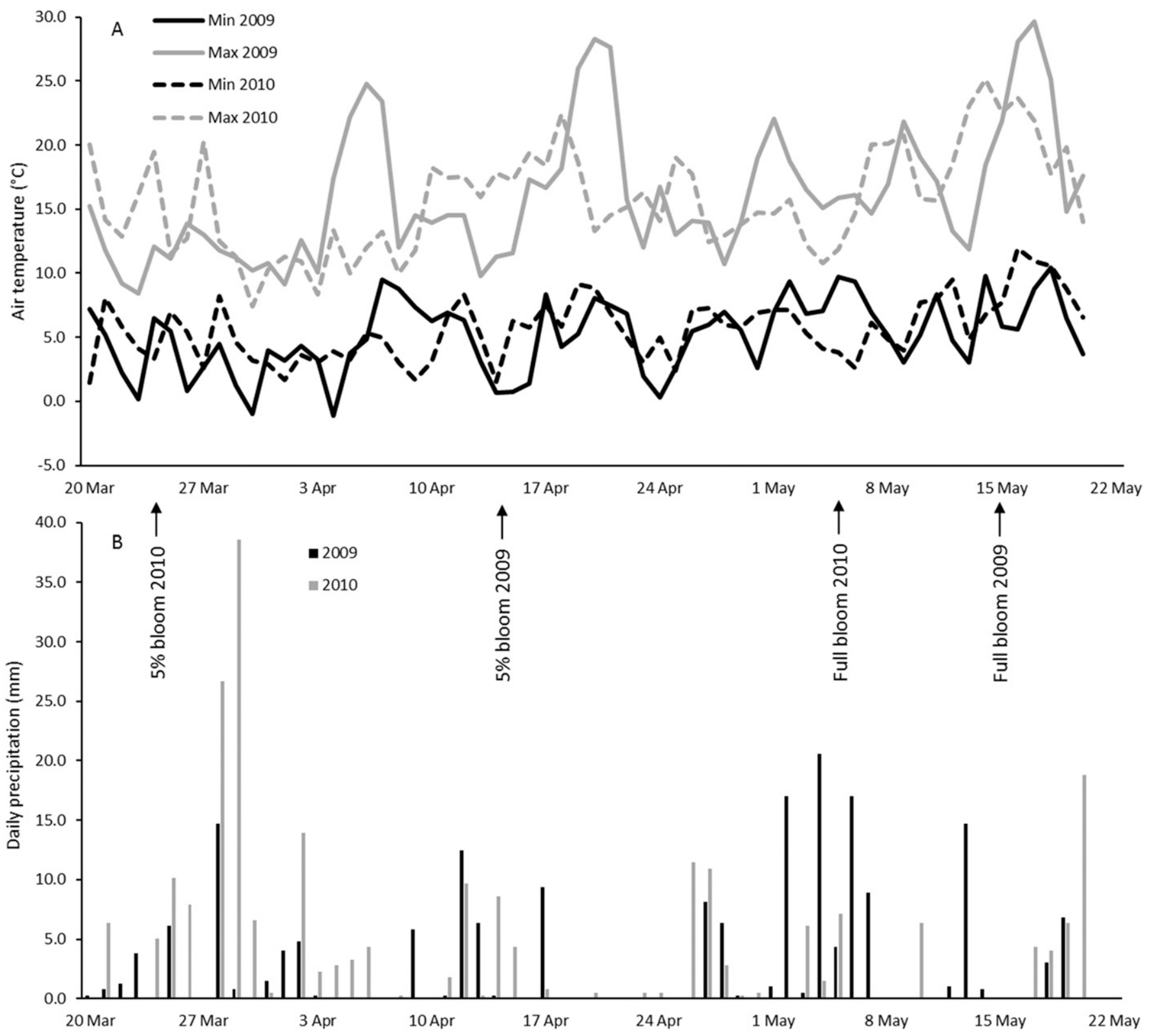

Fig. 1. Maximum and minimum daily air temperature (A) and precipitation (B) in 2009 and 2010 from 20 Mar. to 22 May at Oregon State University's North Willamette Research and Extension Center, Aurora, OR. The earliest date for 5\% bloom and the latest date for full bloom are indicated. Weather data from an on-site AgriMet weather station (U.S. Dept. Interior, 2014). 

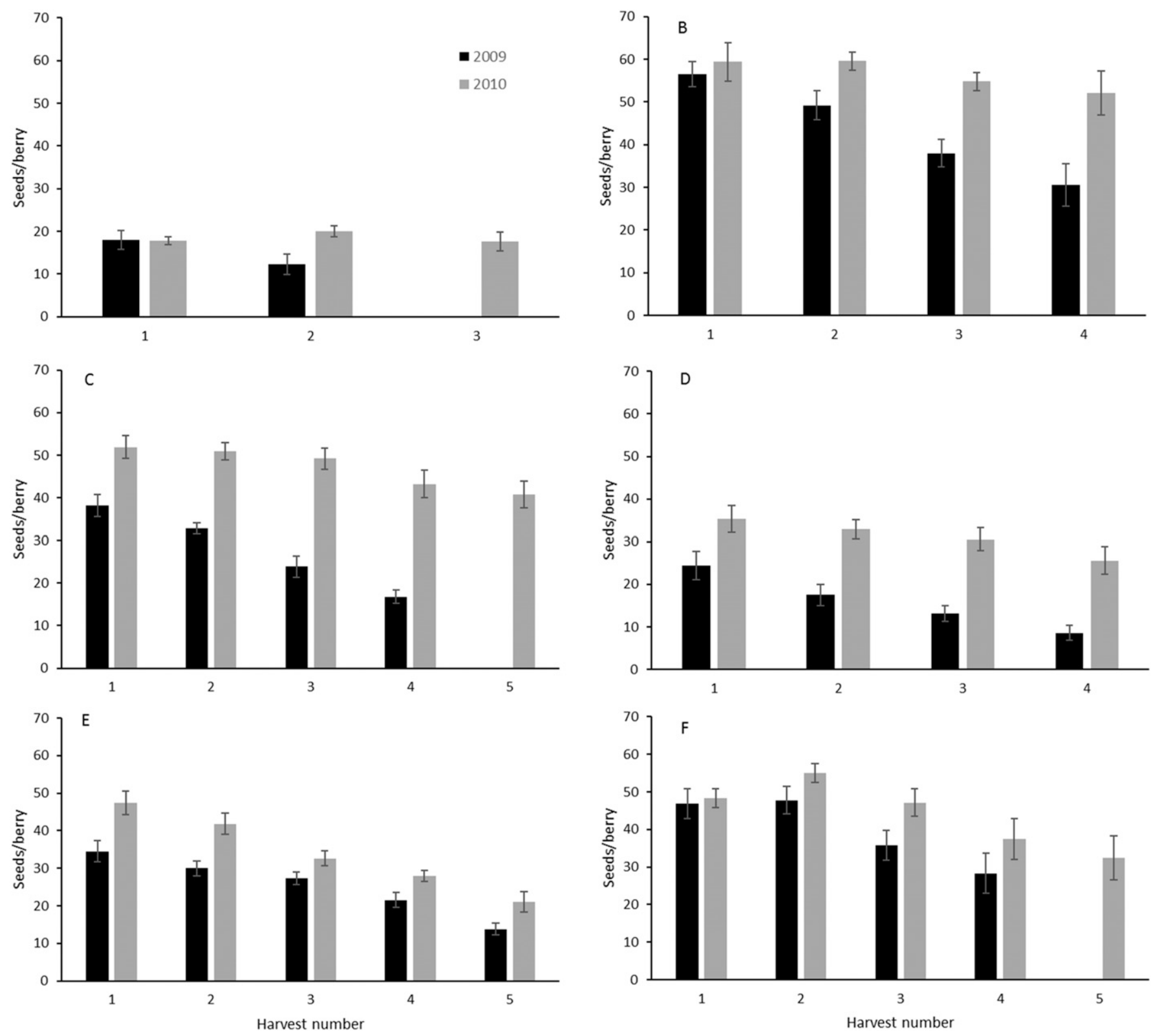

Fig. 2. Relationship of harvest number (1-5, depending on the cultivar) and year (2009 and 2010) on the seeds/berry of (A) 'Bluegold', (B) 'Duke', (C) 'Legacy', (D) 'Liberty', (E) 'Ozarkblue', and (F) 'Reka', averaged over berry size category. Error bars represent $\pm 1 \mathrm{SE}$.

There was a year by harvest number interaction on berry weight in all of the cultivars (Fig. 3) except for 'Draper' (Table 2). In most cultivars, berry weight was greater in 2010 than in 2009 for all harvests, but differences between years were greater in the second and subsequent harvests than for the first harvest (Fig. 3).

Because berries were divided into categories by their diameter to ensure a range in berry weights and potential seed number, seeds/berry and berry weight differed by size category in all cultivars (Table 2). In general, large-diameter berries had more seeds than small-diameter berries as found by Jackson et al. (1972). There was, however, quite a range in seeds/berry by size category. For example, some cultivars had a considerable difference in the number of seeds in largesized $(>19 \mathrm{~mm})$ compared with small-sized berries $(<15 \mathrm{~mm})$ (e.g., 89\%, 107\%, 108\%, and $147 \%$ more seeds in 'Aurora', 'Reka', 'Bluegold', and 'Liberty', respectively), whereas others had relatively little difference (14\% and $36 \%$ in 'Draper' and 'Bluecrop', respectively); 'Legacy' and 'Duke' were in between ( $45 \%$ and $54 \%$, respectively). On average, medium-sized berries had from 3\% ('Draper') to $86 \%$ ('Liberty') more seeds than small-sized berries. There was a year by berry size category interaction for seeds/ berry for 'Bluegold', 'Legacy', and 'Reka' and for berry weight in 'Bluegold', 'Draper', 'Legacy', and 'Liberty' (Table 2). In 'Bluegold', although the seeds/berry was similar for large- and medium-sized fruit in both years, small-sized fruit had almost double the seeds in 2010 compared with 2009 (data not shown). In 'Reka', small- and medium-sized fruit had slightly more seeds/berry in 2010 than in 2009, but large fruit were similar between years. In 'Legacy', berries in all size categories had more seeds in 2010 than in 2009, but particularly in large fruit (data not shown).

There was a harvest number by berry size category interaction on seeds/berry for 'Duke', 'Ozarkblue', and 'Reka' and for berry weight in 'Bluegold', 'Draper', 'Duke', 'Legacy', 'Ozarkblue', and 'Reka' (Table 2). 'Duke' fruit maintained a high number of seeds/berry for medium- and large-sized fruit through the harvest season, as did 'Reka' (Fig. 4). However, the seeds/berry declined through the harvest period for all size categories in 'Ozarkblue'. In general, for cultivars where there was an interaction between harvest number and berry size category for berry weight, there was more of a difference between the weight of small-, medium-, and 

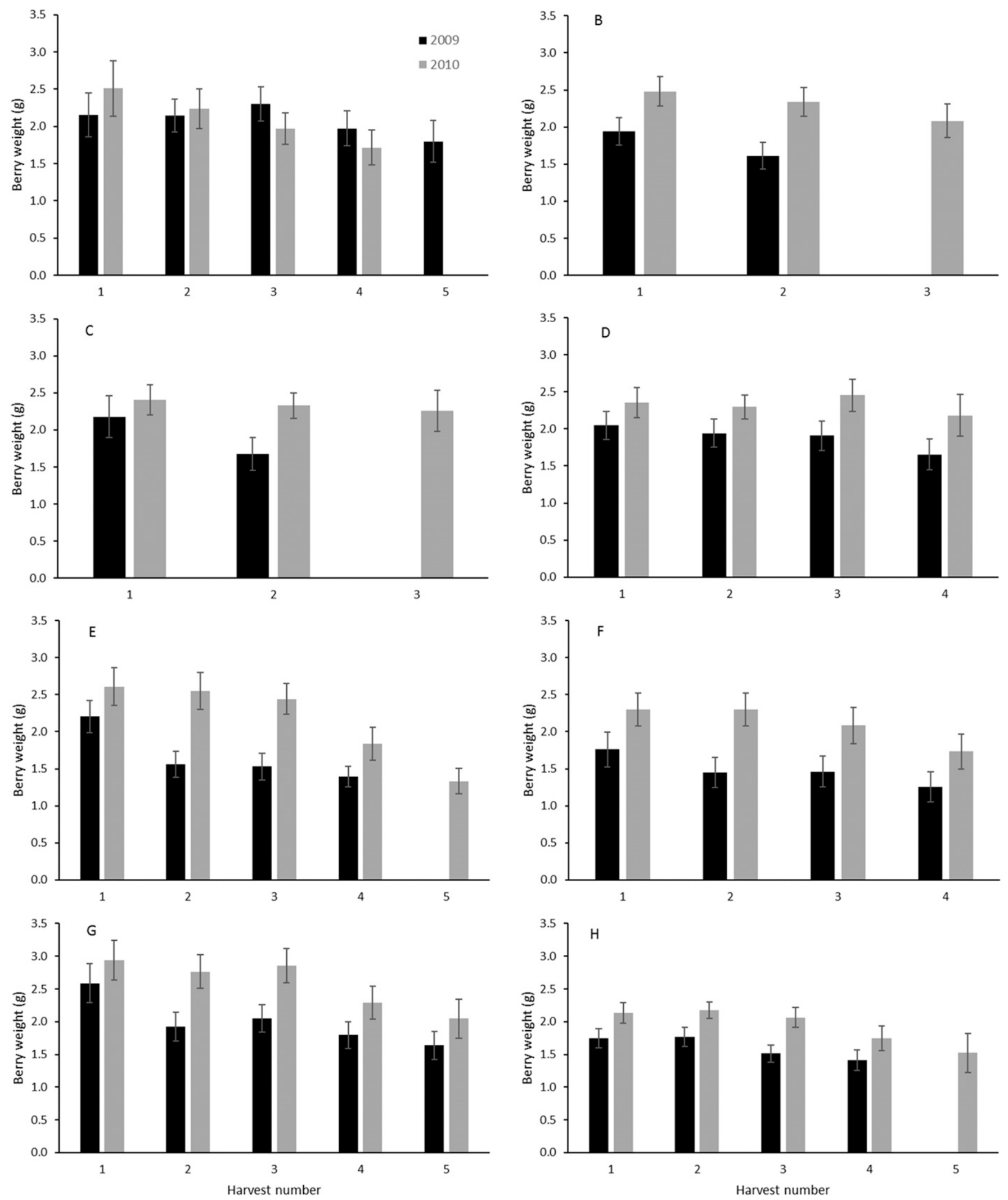

Fig. 3. The relationship of harvest number (1-5, depending on the cultivar) and year (2009 and 2010) on the berry weight of (A) 'Aurora', (B) 'Bluecrop', (C) 'Bluegold', (D) 'Duke', (E) 'Legacy', (F) 'Liberty', (G) 'Ozarkblue', and (H) 'Reka', averaged over berry size category. Error bars represent \pm 1 sE.

large-sized fruit on the last harvest date than earlier harvests (data not shown).

Seed number effect on berry weight. There was a significant linear relationship between berry weight and viable seeds/berry for all cultivars in both years, except for 'Draper' in 2010 (Table 3; Fig. 5). Cultivars did not differ in the berry weight per seed (slope of the line) between the 2 years, except for 'Draper' (only significant in 2009), 'Legacy', and
'Reka'. 'Bluegold' had the greatest berry weight per seed (94-102 mg/seed). A large group of cultivars had intermediate slopes, including 'Aurora', 'Bluecrop', 'Draper', 'Legacy’ (2010), 'Liberty’, and 'Ozarkblue'. 

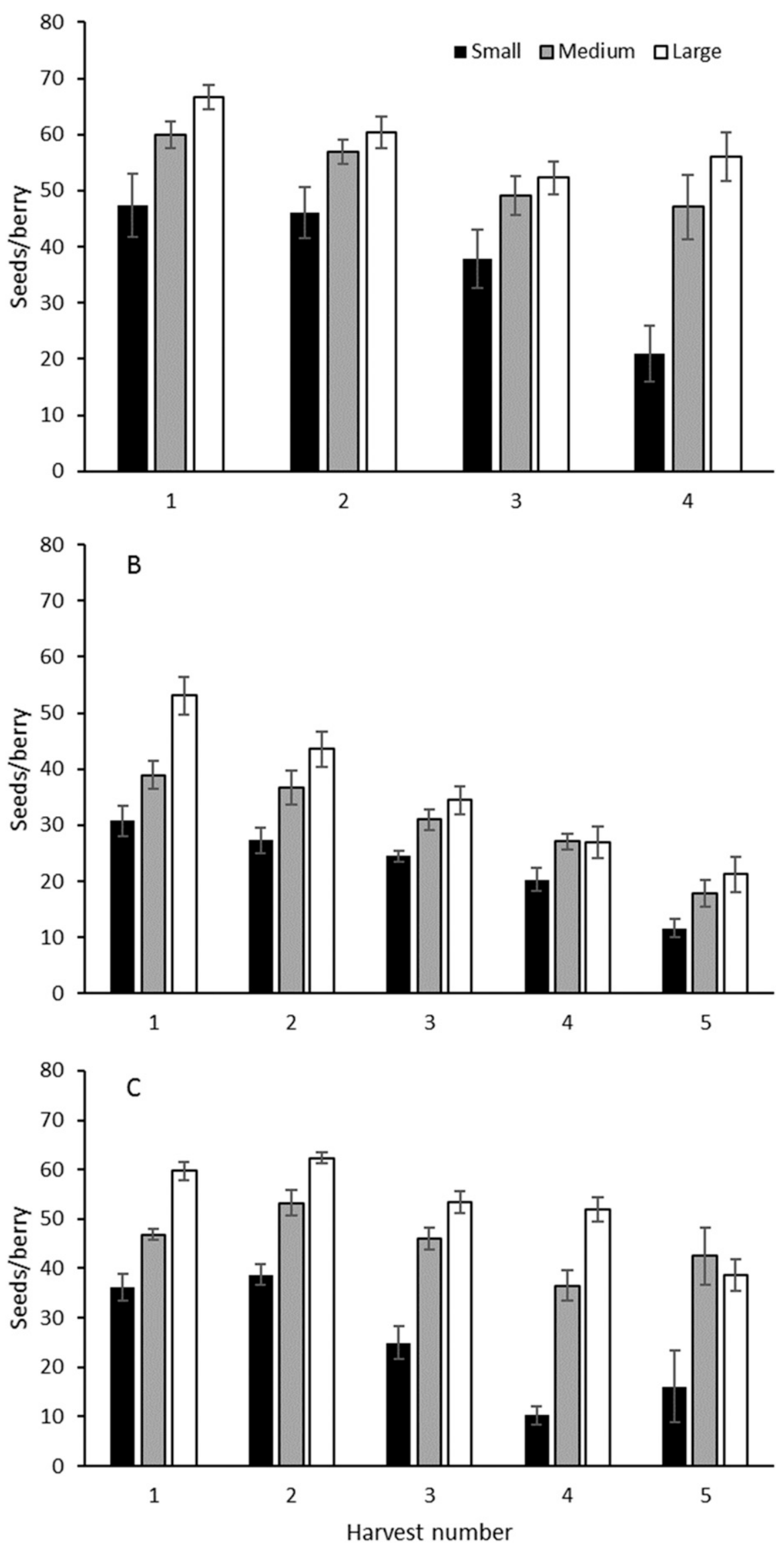

Fig. 4. The relationship of harvest number $(1-5$, depending on cultivar) and berry size category $($ small $=$ $<15 \mathrm{~mm}$ diameter; medium $=15-19 \mathrm{~mm}$; large $=>19 \mathrm{~mm}$ ) on the seeds/berry for (A) 'Duke', (B) 'Ozarkblue', and (C) 'Reka', averaged over year. Error bars represent \pm 1 SE.
'Reka' had the smallest slope of the line, particularly in 2009 (29 mg/seed). Both 'Reka' and 'Liberty' had the strongest relationship between berry weight and seed number in both years (high $R^{2}$; Table 3 ). The weakest relationship between berry weight and seed number was in 'Draper' where it was only significant in 2009 and was relatively weak (low $R^{2}$ ), e.g., berries with 30 seeds produced anywhere from 0.75 to $3.0 \mathrm{~g}$ fruit (Fig. 5D). Our findings are counter to those of Ehlenfeldt and Martin (2010), who found no significant linear relationship between berry weight and seeds/ berry in 'Duke'. Our results agree with others, who reported an increase in the number of fully developed seeds was associated with an increase in berry size in some or all of the highbush blueberry cultivars studied (DeVetter et al., 2016; Ehlenfeldt, 2001; Ehlenfeldt and Martin, 2010; Gupton, 1984; Gupton and Spiers, 1994; Lang and Danka, 1991; Lyrene, 1989; Meader, 1936; Meader and Darrow, 1944; Moore et al., 1972).

The berry weight per seed (slope of line in Table 3) ranged from 29-102 $\mathrm{mg} / \mathrm{seed}$ depending on cultivar, similar to values reported by others (Ehlenfeldt, 2001; Moore et al., 1972) but greater than what was reported by Eaton (1967). Similar prior work found that cultivars differed in the berry weight developed per seed (Bailey, 1938; Brewer and Dobson, 1969; Eaton, 1967; Gupton, 1984; Knight and Scott, 1964; Lyrene and Goldy, 1983; Meader and Darrow, 1944; Rabaey and Luby, 1988; Taber and Olmstead, 2016). Fruit enlargement in blueberry is thought to be stimulated by growth hormones produced by the fertilized ovules or developing seeds (Mainland and Eck, 1968; Meader and Darrow, 1944, 1947). Cultivars may differ in the amount of stimulating growth hormone produced per seed (Meader and Darrow, 1944; Moore et al., 1972) leading to the observed differences. In the case of no or little seed set, parthenocarpic fruit may be induced by exogenous application of gibberellic acid, but in such cases, fruit do not attain the size of pollinated fruit with seeds (Barker and Dobson, 1969; Williamson et al., 1995). Differences in size between pollinated and parthenocarpic fruit treated with gibberellic acid were due to more cell enlargement in pollinated fruit rather than more cell division (Cano-Medrano and Darnell, 1997).

Results of regression analysis indicated that cultivars with a positive intercept ('Bluegold', 'Duke', 'Ozarkblue', and 'Reka', and 'Aurora', 'Legacy', and 'Liberty' in 2009) may produce a berry without any seeds (parthenocarpic) (Table 3). However, based on the data collected, cultivars that did produce parthenocarpic fruit of marketable size $(0.5 \mathrm{~g})$ were 'Aurora', 'Bluegold', and 'Liberty' (all in 2009 only) (Fig. 5). In addition, 'Duke', 'Legacy', 'Reka', and 'Ozarkblue' produced commercially acceptable fruit $(0.75-1.0 \mathrm{~g})$ in 2009 with fewer than 7 seeds/berry. By contrast, some cultivars required a relatively large number of seeds to 
produce a berry, including 'Bluecrop' (28-40 seeds), 'Draper' (15-23 seeds), and 'Legacy' in 2010 (20 seeds) (Fig. 5). Our findings of 'Bluecrop' having low levels of parthenocarpy compared with 'Duke' agree with MacKenzie (1997) and Ehlenfeldt and Martin (2010).

In some cultivars, the stimulation of pollination and perhaps even fertilization of ovules with early abortion of embryos (no full seed development) may increase berry size (Meader and Darrow, 1944). However,
Moore et al. (1972) found a weak relationship between berry weight and total seed number (including those not fully developed) in various cultivars grown in a mixed planting (outcross pollination likely). Also Dogterom et al. (2000) found that excess pollen (outcross rather than self) did not result in $100 \%$ seed set or an increase in fruit weight. Although we found a strong impact of seeds/berry on berry weight, the amount of berry weight per seed varied with cultivar, and large berries among cultivars differed in

Table 3. The results from linear regression analysis of berry weight on the number of viable seeds/berry for nine northern highbush blueberry cultivars in each of 2 years. Data include all harvest dates and berry size categories.

\begin{tabular}{|c|c|c|c|c|c|c|}
\hline \multirow[b]{2}{*}{ Cultivar } & \multirow[b]{2}{*}{ Yr } & \multirow{2}{*}{$\begin{array}{c}\text { Linear regression } \\
\text { equation }^{z}\end{array}$} & \multirow[b]{2}{*}{$R^{2}$} & \multirow[b]{2}{*}{$P$ value } & \multicolumn{2}{|c|}{$95 \%$ Confidence interval of the slope } \\
\hline & & & & & Lower limit & Upper limit \\
\hline \multirow[t]{2}{*}{ Aurora } & 2009 & $y=0.070 x+0.670$ & 0.5295 & $<0.0001$ & 0.053 & 0.088 \\
\hline & 2010 & $y=0.084 x-0.160$ & 0.7086 & $<0.0001$ & 0.067 & 0.102 \\
\hline \multirow[t]{2}{*}{ Bluecrop } & 2009 & $y=0.063 x-0.853$ & 0.6009 & $<0.0001$ & 0.040 & 0.086 \\
\hline & 2010 & $y=0.051 x-1.025$ & 0.5873 & $<0.0001$ & 0.036 & 0.066 \\
\hline \multirow[t]{2}{*}{ Bluegold } & 2009 & $y=0.094 x+0.502$ & 0.7634 & $<0.0001$ & 0.070 & 0.118 \\
\hline & 2010 & $y=0.102 x+0.444$ & 0.5468 & $<0.0001$ & 0.070 & 0.134 \\
\hline \multirow[t]{2}{*}{ Draper } & 2009 & $y=0.069 x-0.106$ & 0.3142 & 0.0004 & 0.033 & 0.104 \\
\hline & 2010 & - & 0.0583 & $\mathrm{NS}^{\mathrm{y}}$ & - & - \\
\hline \multirow[t]{2}{*}{ Duke } & 2009 & $y=0.031 x+0.542$ & 0.5353 & $<0.0001$ & 0.022 & 0.039 \\
\hline & 2010 & $y=0.037 x+0.211$ & 0.4171 & $<0.0001$ & 0.024 & 0.050 \\
\hline \multirow[t]{2}{*}{ Legacy } & 2009 & $y=0.042 x+0.501$ & 0.4400 & $<0.0001$ & 0.028 & 0.056 \\
\hline & 2010 & $y=0.073 x-1.306$ & 0.6871 & $<0.0001$ & 0.060 & 0.086 \\
\hline \multirow[t]{2}{*}{ Liberty } & 2009 & $y=0.062 x+0.503$ & 0.7191 & $<0.0001$ & 0.050 & 0.073 \\
\hline & 2010 & $y=0.072 x-0.118$ & 0.8127 & $<0.0001$ & 0.061 & 0.082 \\
\hline \multirow[t]{2}{*}{ Ozarkblue } & 2009 & $y=0.063 x+0.391$ & 0.5559 & $<0.0001$ & 0.048 & 0.078 \\
\hline & 2010 & $y=0.055 x+0.677$ & 0.5175 & $<0.0001$ & 0.041 & 0.070 \\
\hline \multirow[t]{2}{*}{ Reka } & 2009 & $y=0.029 x+0.469$ & 0.8730 & $<0.0001$ & 0.025 & 0.032 \\
\hline & 2010 & $y=0.037 x+0.296$ & 0.8270 & $<0.0001$ & 0.032 & 0.042 \\
\hline
\end{tabular}

${ }^{\mathrm{z}}$ Equation from linear regression $y=$ berry weight $(\mathrm{g}) ; x=$ number of seeds per berry.

${ }^{\mathrm{y}}$ Not significant $(P>0.05)$.
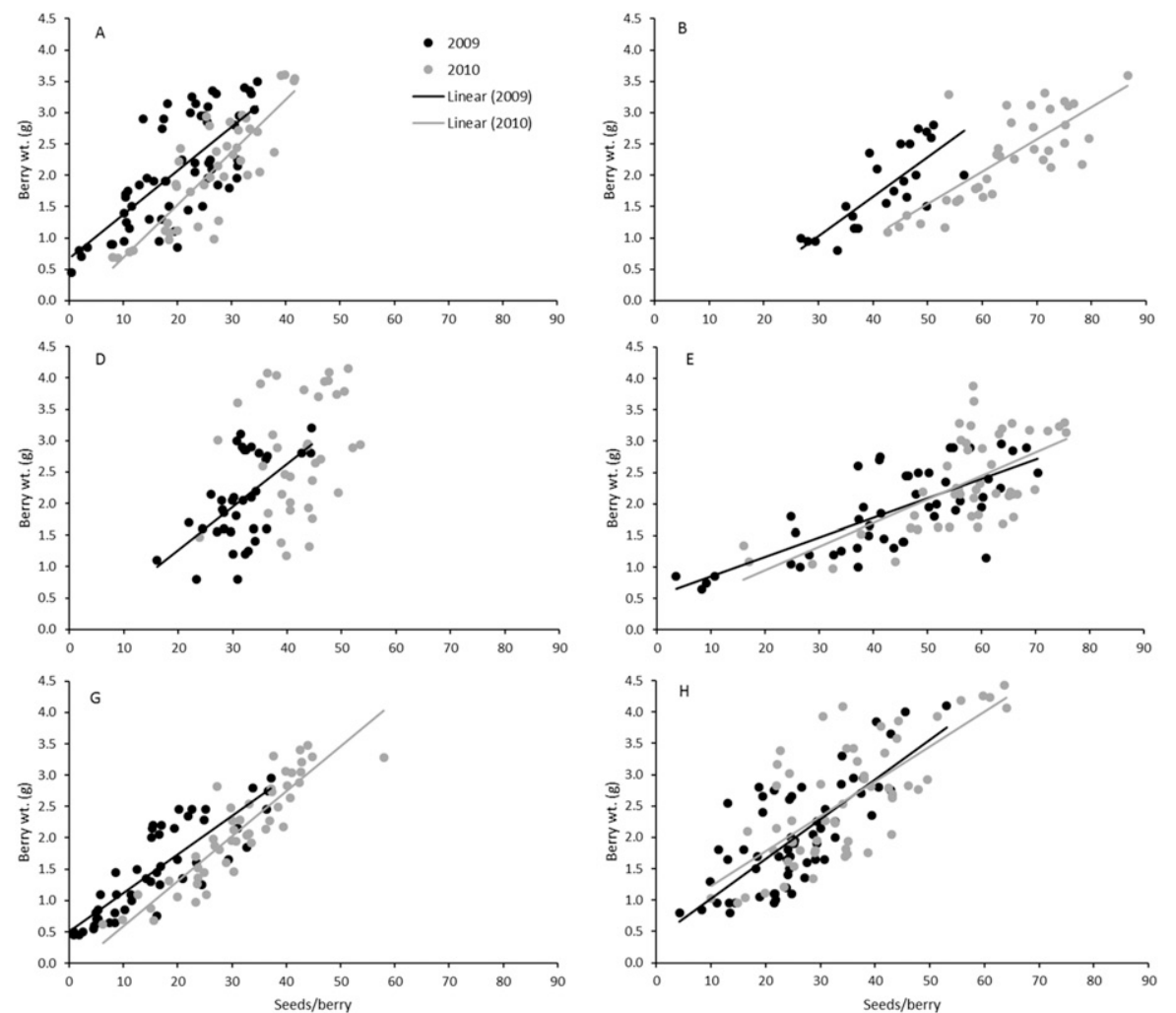

viable seed number. For example, 3.5 to $4.0 \mathrm{~g}$ fruit had as few as 30 seeds in 'Aurora' to 85 seeds in 'Bluecrop' (Fig. 5A and B). Darrow (1958) noted that cultivars with the largest berries did not always have the most seeds/ berry.

In past studies, seeds/berry accounted for a relatively small percentage of the variability in berry weight [e.g., less than $40 \%$ in Eaton (1967); 37\% to 47\% ('Rubel') in Brewer and Dobson (1969); and 8\% (in 'Legacy') to 46\% (in 'Duke') in Ehlenfeldt (2001)]. In addition, Brewer and Dobson (1969) and Eaton (1967) hypothesized that a certain number of seeds was needed to produce a typical sized fruit for the cultivar, but seed numbers above this threshold led to no further increase in berry size. Although others have speculated that the majority of variation in berry weight may be caused by factors other than seeds/berry, we found that seeds/berry accounted for as much as $87 \%$ of the variability in berry weight (Table 3 ). Differences between our results and prior studies may be related to sampling because we measured individual berry weight with corresponding seed number (not pooled samples using averages) for berries of different size categories (30 berries per experimental unit) and harvest numbers to obtain a wide range of fruit per cultivar. We hypothesize that the total viable seeds/berry are more limited by ovule number per flower and the percent seed set. Although we do not know percent seed set, we found no evidence that there was a threshold in berry weight at a high number of viable seeds. Seed set may
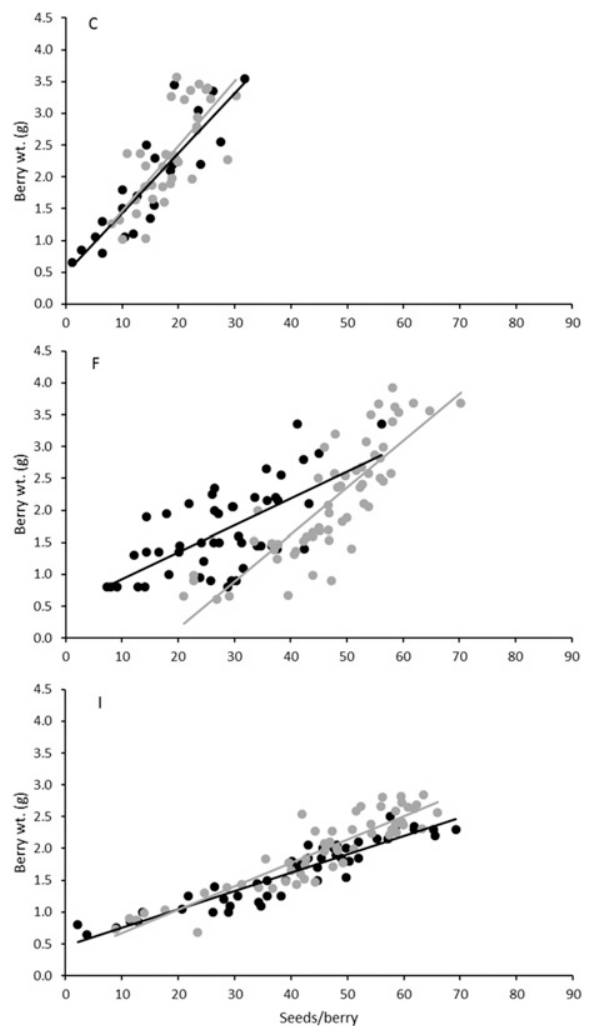

Fig. 5. Linear regression of berry weight on seeds/berry in 2009 and 2010 for (A) ‘Aurora', (B) ‘Bluecrop', (C) ‘Bluegold', (D) ‘Draper', (E) ‘Duke', (F) ‘Legacy', (G) 'Liberty', (H) 'Ozarkblue', and (I) 'Reka'. Each point represents the average of 10 berries per replicate within each size category and harvest number. 
be limited by levels of endogenous hormones or other resources with these limitations differing among cultivars. Breeders may wish to select for high-quality cultivars that produce a large berry weight per seed and can produce parthenocarpic fruit of marketable size.

The observed variable fruit set of 'Liberty' in our region seems likely due to a low percent fruit set rather than seed set based on our findings. This is especially important considering that the cultivars evaluated in this study were planted in a situation where cross-pollination was not limiting. By contrast, 'Draper' may have issues with fruit drop and variable fruit size because a relatively high number of seeds are required to produce a marketable berry and the relationship between seed number and berry weight varies by year. The very strong relationship between viable seeds/berry and berry weight in all cultivars but 'Draper' stresses the importance of good pollination and seed set for berry weight and yield in these cultivars.

\section{Literature Cited}

Arrington, M. and L.W. DeVetter. 2017. Foliar applications of calcium and boron do not increase fruit set or yield in northern highbush blueberry (Vaccinium corymbosum). HortScience 52:1259-1264.

Arrington, M. and L.W. DeVetter. 2018. Increasing honey bee hive densities promotes pollination and yield components of highbush blueberry in Western Washington. HortScience 53:191194.

Bailey, J.S. 1938. The pollination of the cultivated blueberry. Proc. Amer. Soc. Hort. Sci. 35:7172.

Barker, W.G. and W.B. Collins. 1965. Parthenocarpic fruit set in the lowbush blueberry. Proc. Amer. Soc. Hort. Sci. 87:229-233.

Brewer, J.W. and R.C. Dobson. 1969. Seed count and berry size in relation to pollinator level and harvest date for the highbush blueberry, Vaccinium corymbosum. J. Econ. Ent. 62: 1353-1356.

Cano-Medrano, R. and R.L. Darnell. 1997. Cell number and cell size in parthenocarpic vs. pollinated blueberry (Vaccinium ashei) fruits. Ann. Bot. 80:419-425.

Chavez, D.J. and P.M. Lyrene. 2009. Effects of self-pollination and cross-pollination of $\mathrm{Vacci}$ nium darrowii (Ericaceae) and other low-chill blueberries. HortScience 44:1538-1541.

Chen, Y., J.M. Smagula, W. Litten, and S. Dunham. 1998. Effect of boron and calcium foliar sprays on pollen germination and development, fruit set, seed development, and berry yield and quality in lowbush blueberry (Vaccinium angustifolium Ait.). J. Amer. Soc. Hort. Sci. 123:524-531.

Courcelles, D.M.M., L. Button, and E. Elle. 2013. Bee visit rates vary with floral morphology among highbush blueberry cultivars (Vaccinium corymbosum L.). J. Appl. Entomol. 137: 693-701.

Darrow, G.M. 1958. Seed number in blueberry fruits. Proc. Amer. Soc. Hort. Sci. 72:212-215.

DeVetter, L.W., S. Watkinson, R. Sagili, and T. Lawrence. 2016. Honey bee activity in northern highbush blueberry differs across growing regions in Washington State. HortScience 51: $1228-1232$.

Dogterom, M.H., M.L. Winston, and A. Mukai. 2000. Effect of pollen load size and source (self, outcross) on seed and fruit production in highbush blueberry cv. 'Bluecrop' (Vaccinium corymbosum: Ericaceae). Amer. J. Bot. 87: 1584-1591.

Eaton, G.W. 1967. The relationship between seed number and berry weight in open-pollinated highbush blueberries. HortScience 2:14-15.

Ehlenfeldt, M.K. 2001. Self- and cross-fertility in recently released highbush blueberry cultivars. HortScience 36:133-135.

Ehlenfeldt, M.K. and M. Kramer. 2012. Self-fertility evaluations of northern-adapted rabbiteye blueberry hybrids. HortScience 47: 1837-1842.

Ehlenfeldt, M.K. and R.B. Martin, Jr. 2010. Seed set, berry weight, and yield interactions in the highbush blueberry cultivars (Vaccinium corymbosum L.) 'Bluecrop' and 'Duke'. J. Amer. Pomol. Soc. 64:162-172.

Gupton, C.L. 1984. Effect of pollen source on fruit characteristics of low-chilling highbush type blueberries. HortScience 19:53-532.

Gupton, C.L. and J.M. Spiers. 1994. Interspecific and intraspecific pollination effects in rabbiteye and southern highbush blueberry. HortScience 29:324-326.

Jackson, L.P., L.E. Aalders, and I.V. Hall. 1972. Berry size and seed number in commercial lowbush blueberry fields of Nova Scotia. Nat. Can. 99:615-619.

Kirk, A.K. and R. Isaacs. 2012. Predicting flower phenology and viability of highbush blueberry. HortScience 47:1291-1296.

Knight, R.J., Jr., and D.H. Scott. 1964. Effects of temperatures on self- and cross-pollination and fruiting of four highbush blueberry varieties. Proc. Amer. Soc. Hort. Sci. 85:302-306.

Lang, G.A. and R.G. Danka. 1991. Honey-beemediated cross- versus self-pollination of 'Sharpblue' blueberry increases fruit size and hastens ripening. J. Amer. Soc. Hort. Sci 116:770-773.

Lyrene, P.M. 1989. Pollen source influences fruiting of 'Sharpblue' blueberry. J. Amer. Soc. Hort. Sci. 114:995-999.

Lyrene, P.M. and R.G. Goldy. 1983. Cultivar variation in fruit set and number of flowers per cluster in rabbiteye blueberry. HortScience 18:228-229.

MacKenzie, K.E. 1997. Pollination requirements of three highbush blueberry (Vaccinium corymbosum L.) cultivars. J. Amer. Soc. Hort. Sci. 122:891-896.

Mainland, C.M. and P. Eck. 1968. Growth regulator survey for activity in inducing parthenocarpy in the highbush blueberry. HortScience 3:170-172.

May, J.D. and K.T. Killingbeck. 1992. Effects of preventing nutrient resorption on plant fitness and foliar nutrient dynamics. Ecology 73:1868-1878.

Meader, E.M. 1936. Pollination of the highbush blueberry. Mich. Agr. Exp. Sta. Tech. Bull. 151.

Meader, E.M. and G.M. Darrow. 1944. Pollination of the rabbiteye blueberry and related species. Proc. Amer. Soc. Hort. Sci. 45:267-274.

Meader, E.M. and G.M. Darrow. 1947. Highbush blueberry pollination experiments. Proc. Amer. Soc. Hort. Sci. 49:196-204.

Moore, J.N. 1964. Duration of receptivity to pollination of flowers of the highbush blueberry and the cultivated strawberry. Proc. Amer. Soc. Hort. Sci. 85:295-301.
Moore, J.N., B.D. Reynolds, and G.R. Brown 1972. Effects of seed number, size, and development on fruit size of cultivated blueberries. HortScience 7:268-269.

Morrow, E.B. 1943. Some effects of crosspollination versus self-pollination in the cultivated blueberry. Proc. Amer. Soc. Hort. Sci. 42:469-472.

Northwest Center for Small Fruits Research. 2018. Blueberry research priorities. 15 Apr. 2019. $<$ http://www.nwsmallfruits.org/priorities/201819_NCSFR_priorities_rev2016_B_blueberry. pdf $>$.

Oregon Blueberry Commission. 2018. Request for proposals - Research priorities. 15 Apr. 2019 $<\mathrm{https}$ ://agresearchfoundation.oregonstate.edu/ sites/agresearchfoundation.oregonstate.edu/ files/blueberry_research_rfp_2019-20.pdf > .

Patil, V.N. and M.V. Dadlani. 2009. Tetrazolium test for seed viability and vigour. In: M.B. McDonald and F.Y. Kwon (eds.). Flower seeds: Biology and technology handbook. Oxfordshire, UK. 15 Apr. 2019. <https://seednet.gov. in/PDFFILES/Chapter\%2014.pdf>.

Payne, J.A., A.A. Amis, J.H. Cane, and P.M Lyrene. 1989. Fruit size, seed size, seed viability and pollination of rabbiteye blueberries (Vaccinium ashei Reade). Acta Hort. (241): $38-43$.

Rabaey, A. and J. Luby. 1988. Fruit set in half-high blueberry genotypes following self and cross pollination. Fruit Var. J. 42:126-129.

Stephenson, A.G., T-C. Lau, M. Quesada, and J.A. Winsor. 1992. Factors that affect pollen performance, p. 119-134. In: R. Wyatt (ed.). Ecology and evolution of plant reproduction. Chapman \& Hall, New York.

Strik, B.C. and A. Vance. 2015. Seasonal variation in leaf nutrient concentration of northern highbush blueberry cultivars grown in conventional and organic production systems. HortScience 50:1453-1466.

Strik, B.C., C.E. Finn, and P.P. Moore. 2014. Blueberry cultivars for the Pacific Northwest. Oregon. Ore. State Univ. Ext. Serv. PNW 656. 15 Apr. 2019. <http://ir.library.oregonstate. edu/xmlui/bitstream/handle/1957/45871/ pnw656.pdf>.

Strik, B.C., A.J. Vance, and C.E. Finn. 2017. Northern highbush blueberry cultivars differed in yield and fruit quality in two organic production systems from planting to maturity. HortScience 52:844-851.

Taber, S.K. and J.W. Olmstead. 2016. Impact of cross- and self-pollination on fruit set, fruit size, seed number, and harvest timing among 13 southern highbush blueberry cultivars. HortTechnology 26:213-219.

Tuell, J.K. and R. Isaacs. 2010. Weather during bloom affects pollination and yield of highbush blueberry. J. Econ. Entomol. 103:557-562.

U.S. Department of Interior. 2014. Bureau of reclamation, Boise, ID. AgriMet Weather Station web site. 15 Apr. 2019. <www.usbr.gov/ $\mathrm{pn} /$ agrimet/agrimetmap/araoda.html $>$.

Vander Kloet, S.P. 1983. The relationship between seed number and pollen viability in Vaccinium corymbosum L. HortScience 18:225-226.

Washington Blueberry Commission. 2018. Request for proposals-Research priorities. 15 Apr. 2019. <http://www.wablueberrycomm.org/ Content/ImageLib/2018wbcrequestforproposals.pdf $\$$.

Williamson, J.G., R.L. Darnell, G. Krewer, J. Vanerwegen, and S. NeSmith. 1995. Gibberellic acid: A management tool for increasing yield of rabbiteye blueberry. J. Small Fruit Viticult. 3:203-218. 